The University of Southern Mississippi

The Aquila Digital Community

Faculty Publications

$1-1-2020$

\title{
American Buddhist Protection of Stones In Terms of Climate Change On Mars and Earth
}

Daniel Capper

University of Southern Mississippi, Daniel.Capper@usm.edu

Follow this and additional works at: https://aquila.usm.edu/fac_pubs

Part of the Buddhist Studies Commons

\section{Recommended Citation}

Capper, D. (2020). American Buddhist Protection of Stones In Terms of Climate Change On Mars and Earth. Contemporary Buddhism.

Available at: https://aquila.usm.edu/fac_pubs/19130

This Article is brought to you for free and open access by The Aquila Digital Community. It has been accepted for inclusion in Faculty Publications by an authorized administrator of The Aquila Digital Community. For more information, please contact Joshua.Cromwell@usm.edu. 
This essay is forthcoming in Contemporary Buddhism.

https://doi.org/10.1080/14639947.2020.1734733

\title{
AMERICAN BUDDHIST PROTECTION OF STONES IN TERMS OF CLIMATE CHANGE ON MARS AND EARTH
}

\author{
Daniel Capper, Ph.D. \\ Professor \\ School of Humanities \\ University of Southern Mississippi \\ 118 College Drive, \#5037 \\ Hattiesburg, MS 39406 \\ Daniel.Capper@usm.edu \\ 601-266-4522 \\ ORCiD: 0000-0001-5797-8083
}

\section{Biographical note:}

Daniel Capper, Ph.D., Professor at the University of Southern Mississippi, is a specialist within religious studies on Buddhism, science, and the environment. With degrees from the University of Virginia and the University of Chicago, he has published the books Guru Devotion and the American Buddhist Experience and Learning Love from a Tiger: Religious Experiences with Nature as well as finished a forthcoming manuscript, Roaming Free like a Deer: Buddhism and the Natural World. Currently he is working on a research project regarding American Buddhist environmental ethics in space, as evidenced by his web site buddhismandspace.org. 


\begin{abstract}
:
A number of scientific writers have proposed manipulating the ecology of Mars in order to make the planet more comfortable for future immigrants from Earth. However, the ethical acceptability of such 'terraforming' proposals remains unresolved. In response, in this article I explore some of these scientific proposals through the lens provided by Buddhist environmental ethics that are quantitatively expressed by practitioners in the ethnographic field of the United States. What I find is that contemporary Buddhists combine philosophical notions of interconnectedness with moral considerations not to harm others and then creatively extend this combined sensibility to the protection specifically of abiotic features of Mars. In so doing these Buddhists significantly reject proposals to alter the Martian ecology planet-wide as beyond the ethical right of humans. Along the way these Buddhists also importantly provide an innovative basis for enriching Buddhist environmental ethical protection of abiotic locations, and this strengthening can assist in mitigating climate change on Earth.
\end{abstract}

\title{
Keywords:
}

American Buddhism, climate change, environmental ethics, Mars, planet-wide ecological manipulation, terraforming

\section{Disclosure:}

This research did not receive any specific grant from funding agencies in the public, commercial, or not-for-profit sectors.

The author received no financial compensation of any kind. 
American Buddhist Protection of Stones in terms of Climate Change on Mars and Earth

\section{Introduction}

In his futuristic work Genesis: An Epic Poem of the Terraforming of Mars, Professor Frederick Turner (2011) offers a fascinating fiction-based meditation on the oft-proposed planet-wide ecological manipulation of the Red Planet. In Turner's story the leader of the United Nations mission to Mars, Chance Van Riebeck, violates regulations by introducing bioengineered organisms into the Martian ecosystem in order to make the planet's environment more Earthlike and hence more comfortable for human colonists. Aiding the establishment of these organisms, some of Van Riebeck's followers purloin an ice moon of Saturn, rename it Comet Kali, and intentionally smash it into Mars in order to gain gases to thicken the Martian atmosphere and water to support imported life (131). With a richer atmosphere, Mars becomes warmer, and plants, animals, and running water abound, so that Mars more closely resembles contemporary Earth. In the course of this process, various characters in Turner's story supply critiques both in favor of and opposing this type of planetary ecological manipulation, engendering many analytic hues within the poem. Nonetheless, in the end the proponents of renovating Mars win, the planet's atmosphere becomes humid and breathable for humans, and 'a new branch of natural history' (310) results from the wholesale bio- and geo-engineered makeover of the world.

While Turner's poem should be recommended for its intelligence and originality, many other science fiction writers have explored the planet-wide ecological manipulation of Mars, perhaps most notably Kim Stanley Robinson (1993, 1994, 1996). But the idea of transforming planetary ecologies arises in academic scientific nonfiction as well, like that of Fogg (1995). Indeed, as the NASA astrobiologist Christopher P. McKay states, 'The scientific community considers planetary ecosynthesis on Mars as a serious topic in space research' (McKay 2009, 254). It is these nonfictional, scientific proposals that occupy my focus in this essay, which ethnographically explores American Buddhist ethical responses to such scenarios. It should be recognised that there are gradations in 
these proposals, from small alterations of the planet intended to encourage very local life forms to planet-wide changes aimed to benefit immigrants from Earth. In this essay I restrict my gaze to the second, large-scale and Earthling-friendly type of planetary transformation in examining proposals by the scientific writers Beech (2009) and Zubrin (1996).

I exclude Earth geoengineering from my ecological manipulation analysis, because making Earth more friendly to Earth life remains a morally, ecologically, financially, and practically different affair from making Mars more comfortable for Earthlings. In fact, as I will share more in the Discussion section, attitudes among Buddhists in this study toward the ecological manipulation of Mars retain useful ethical application for mitigating climate change on Earth by morally directing lithospheric carbon sequestration strategies, which transform atmospheric carbon dioxide into stone.

Whether in science journals or fiction, large-scale planetary alterations of Mars often are called 'terraforming,' although one also can find other terms in the scientific literature such as 'planetary ecosynthesis' (Graham 2004, 168) or 'planetary ecopoiesis' (Haynes 1990, 161). In this essay I will eschew these misleading euphemisms. If I were to dig a hole in my back yard to install a swimming pool, that technically is 'terraforming,' or 'shaping Earth.' Yet intentionally altering an entire planet's atmosphere is a different pursuit than is building a swimming pool, so especially on a nonEarth planet the word 'terraforming' misses the mark. Likewise, 'planetary ecosynthesis' sounds rather polite, and 'ecopoiesis,' 'home making,' has a comforting ring to it. But, as I will share more fully, Buddhists in this study two-to-one reject the practice, many of them considering it neither polite nor comforting. Therefore, in this essay I will denote this practice descriptively by what it intends: planet-wide ecological manipulation.

Despite the frequency with which the planet-wide ecological manipulation of Mars appears in literature as well as the practice's role as 'the poster-boy problem of space ethics' (Milligan 2015,8) due to its centrality, the morality of the practice remains quite unresolved, as the space ethicist Tony Milligan ably explores in Nobody Owns the 
Moon. Some ethicists, like Robert Sparrow (1999), argue definitively against planetwide ecological manipulation, while others, such as James S. J. Schwartz (2013), find no intrinsic ethical problem with ecologically overhauling planets. Part of this lack of resolution derives from the weakness in protecting abiotic entities like stone found across many systems of environmental ethics (Capper 2016a, 245-246). While life may exist on Mars but be hidden for now (Weintraub 2018,4), today preserving the environment of Mars presumably involves protecting abiotic locations, and environmental ethics arguments regarding abiotic spots remain difficult to make, including within Buddhist ethical worlds (Capper 2015, 65-67).

Thus, one goal of this essay is to ameliorate this weakness within Buddhist environmental ethics by finding arguments for the protection of abiotic places like the regolith (assorted surface rocks and sands) of Mars. As another provision, by turning to Mars as an ideal laboratory for developing abiotic environmental ethics due to the focus on geodiversity that the planet affords, I counteract a 'life-bias in planetary protection ethics... that we can and should overcome' (Schwartz 2016b, 31). This dynamic provides a new perspective within the space ethics debate regarding the appropriateness of planet-wide ecological manipulation. Therefore, this essay, residing at the intersection of Buddhist studies and astrobiology, intends to contribute novel and helpful advances within both Buddhist environmental ethics and space science, although no one should expect these contributions to represent the last words on the respective issues.

These contributions arise from the ethnographic voices of American Buddhists, who provide a new understanding of the tradition and thereby enable innovative approaches to the related issues of protecting abiotic places, the ecological manipulation of Mars, and even the battle with climate change on Earth. First, I provide context for these Buddhist voices by exploring some scientific and moral arguments in favor of changing the ecology of Mars as well as voices that oppose the practice. I then introduce Buddhist perspectives, beginning with scriptural viewpoints. Since most Buddhist scriptures were written roughly 2,000 years ago, when the ecological manipulation of Mars was not much contemplated, thereafter I supplement scriptural teachings with 
ethnographic American Buddhist expressions. As I will describe more fully, Buddhists from the field on the whole find the proposal to manipulate Mars' ecology untenable, for together they tell us that humans morally do not have the right dramatically to alter an entire planet's ecology. The American Buddhist teacher David R. Loy writes, 'Fantasies about terraforming Mars reveal less about the potential for an extraterrestrial colony than how estranged we have become from our planetary home' (Loy 2018, 115), and many Buddhists in the field appear to feel similarly.

Further, the American Buddhists in this study make a strong case, if a nontraditional one, for protecting and defending abiotic environments because of Buddhist notions of an interconnected universe that arises interdependently (Pāli: paticcasamuppāda) combined with an innovative expansion into abiotic ecologies of the monastic and lay precept against harming others (the ahimsa precept). As such, these Buddhists provide avenues for a more transparent moral understanding regarding the protection of abiotic places, the ecological manipulation of other worlds, and, by extension, mitigation responses to the issue of Earth's climate change. Of course, one cohort of American Buddhists by itself will not overturn the momentum of a 2,500 year old religious tradition, but these practitioners can open the door to new types of Buddhist environmental ethical reflection regarding the lifeless entities upon which life depends, with this revitalised conversation's representing a benefit by itself both for Mars and Earth.

In a final contribution, this article also provides a rare record of lived Buddhist attitudes toward space exploration, which emerges as an impact of its own given the paucity of empirical data on the subject in the scholarly literature. I begin by examining briefly the science of planet-wide ecological manipulation.

\section{Proponents of Ecological Overhaul}

In his book, Terraforming: The Creating of Habitable Worlds, the professor of astronomy Martin Beech (2009) scientifically argues strongly for the planet-wide ecological manipulation not just of Mars, but also of Venus, Jupiter's moon Europa, and 
other locations in our solar system. Beech claims that humans ecologically have sullied their own planet to such an extent that planetary lifeboats are needed in order to 'foster the growth of humanity' (7). Because of our environmental crisis, 'We must either adapt ourselves to expect less, or we must adapt to other worlds, and here is humanity's first big break, for we live in a Solar System full of prime terraforming real estate' (9). We know that we can seriously alter atmospheres quickly, Beech says, so we know that we can change places like Mars rapidly (10), and doing so will allow habitation, if not perfectly Earthlike, by plants, bioengineered animals, and humans (13). Like in Turner's poem, Beech tells us that we can reach this goal by crashing comets into Mars, freeing for use their ammonia gas to warm the atmosphere as well as their water, carbon dioxide, nitrogen, and oxygen. A single comet of $10 \mathrm{~km}$ alone could create dramatic change, Beech relates (151-152). Beech's comet plan, recently shared as well by Professor Genta (2017, 278), may be startling to some readers but remains a staple within planet-wide ecological manipulation strategies, since it appears that Mars lacks the native carbon dioxide deposits to warm the planet or create atmospheric pressure enough to result in real ecological change (Jakosky and Edwards 2018, 634).

After the planet enjoys induced warming from its thicker atmosphere, microbes, lichens, mosses, and trees can be introduced to create biodiversity that usefully alters the Martian atmosphere further (Beech 2009, 160-162). In this way, Beech tells us, we can never make Mars a perfect twin of Earth, but we can make Mars a place where humans can live comfortably in terms of temperature, water resources, food sources, and protection from ultraviolet radiation $(9,143)$. Although Beech follows a 'fractionated' (7), rather than all-or-nothing, approach to planetary manipulation, his proposal still results in the topic of this essay, a large-scale change to Mars' ecology in favor of Earth beings.

In his presentation Beech remains straightforward about his strong anthropocentric ethical presumptions, telling us that his motives exist 'shamelessly on the side of doing what is best for the human race' (11). This strong anthropocentrism also marks the moral arguments for planet-wide ecological manipulation issued by one of the 
most outspoken scientific aficionados of the practice, the aerospace engineer Robert Zubrin. With strong anthropocentric zest Zubrin claims, 'If we can terraform Mars, it will show that the worlds of the heavens themselves are subject to the human intelligent will' (Zubrin 1996, 270), while it demonstrates that 'humans are more than just animals, that we are in fact creatures who carry a unique spark that is worthy of respect' (271). In a flourish Zubrin asserts that changing Mars' ecology represents 'the most profound vindication of the divine nature of the human, exercised in its highest form to bring a dead world to life....Failure to terraform Mars constitutes failure to live up to our human nature and a betrayal of our responsibility as members of the community of life itself' (248-249). For Zubrin, in other words, to be human necessarily is to bring life to lifeless planets.

\section{Against the Ecological Manipulation of Mars}

Both Beech and Zubrin offer arguments for changing Mar's ecology that are moored in attitudes of strong anthropocentrism. Deriving from a more ecocentric point of view, the philosopher Ian Stoner is one of the most recent to argue ethically against the planet-wide ecological manipulation of Mars. Stoner's counter-manipulation argument arises in the context of a larger claim that "we should refuse on moral grounds to establish a human presence on the surface of Mars' (Stoner 2017, 334). Stoner founds this discourse on two moral principles, 'a principle constraining the use of invasive or destructive techniques of scientific investigation' and 'a principle governing appropriate human behavior in wilderness,' (334) and from these principles argues against five reasons commonly given for colonising Mars.

First, Stoner states, colonising Mars to gain the planet's natural resources, like we find in both Beech's and Zubrin's proposals, should be rejected because resources are easier to gain from asteroids (337). A second reason for the colonisation of Mars, to fulfill the pioneering spirit of humanity, fails for Stoner both in terms of doubts about the presence of this spirit and because expanding humanity's footprint has worked out poorly at times in the past (337). Stoner then dismisses the argument that Mars should be 
colonised to provide experiments in human living by asserting that such experiments are best done in lightly inhabited places on Earth (338). With vigor Stoner afterwards disposes of arguments for the human need of a backup planet, like is found at the center of Beech's argument, by stressing, 'A Mars colony would not insure against large-scale threats to the solar system, such as nearby supernovae, invading extraterrestrials, or an early expansion of the sun. Nor would it insure against threats we pose to ourselves, such as war and environmental destruction. We carry these threats to ourselves everywhere we go’ (339-340).

The only reason for colonising Mars with which Stoner can agree is the fifth, to expand scientific knowledge. But, because of his two ethical principles of scientific conservation and treading lightly in wilderness, he considers that the scientific exploration of Mars remains best done by robots, with humans absent (345). From this position, Stoner then emphasises that his two principles mean that the planet-wide ecological manipulation of Mars 'should remain forever science fiction. Any presence we establish on Mars should tread lightly and be minimally invasive, and that goal is incompatible with terraforming the planet' (350).

Each one of these perspectives, both for and against the ecological manipulation of Mars, bears important limitations. Put succinctly, given Beech's exclusive valuation of human welfare, if one values anything else in addition to human welfare, his arguments fall short. Likewise, if one values the nonliving things that make life possible, Zubrin's unilateral favoring of life over nonlife cannot supply a competent ethic. Stoner defines 'wilderness' as 'undeveloped or minimally developed land' (Stoner 2017, 349), a model that implicitly arises from a false dualistic divide between the human and nonhuman natural worlds. As the environmental historian William Cronon (1995, 69-90) has argued, even when physically absent from the ecologies around them, humans participate in some way - for instance culturally - in all of their surrounding environments, including uninhabited places. Therefore, for Cronon, a noninteractive notion of 'wilderness' which is counterposed against the human world, like Stoner's model, lacks conceptual coherence. Given these weaknesses in the arguments of Beech, 
Zubrin, and Stoner, the moral acceptability of the ecological manipulation of Mars remains undetermined.

While I cannot comment much on the scientific feasibility of the planet-wide ecological manipulation of Mars, I can provide some clarity regarding its moral acceptability by turning to ethnographic data collected among American Buddhists in order to examine relevant ethical issues from new vistas. As I will explain more fully, on the whole Buddhists in my study reject the ecological manipulation desired by Beech and Zubrin as something that humans have no right to undertake. In so doing, they counter Beech's strong anthropocentrism with a more ecocentric vision. Interestingly for Buddhists, additionally they implicitly dispute Zubrin's belief that to be human is to spread and support life by highlighting the value of abiotic ecologies against incursions from life forms. These Buddhists further replace the dualism that is built into Stoner's concept of 'wilderness' with a more interactive, relational environmental ethic that emerges from the idea of human interconnectedness with Mars and its features. In so doing, they also uniquely stress the value of nonharm as applied to abiotic ecologies, creating ramifications for Buddhist approaches to Mars as well as the problem of Earth's climate change. I turn now to the voices of these Buddhists beginning with the scriptures that they read.

\section{Context from the scriptures}

The Buddha, who lived in what is now Nepal and India around 500 BCE, left us with a quite large corpus of teachings within scriptures, whether one looks at Buddhism from a Theravāda, Mahāyāna, or Vajrayāna point of view. However, given the Buddha's time period and those of the composers of the scriptures, one does not find direct discussions in the scriptural teachings of the appropriateness of manipulating Mars' ecology. We may find indirect hints at what the Buddha might have said, though, if life of some type is found on Mars. The Buddha gave us strong ethics regarding treating animals with compassion (Pāli: karunā), lovingkindness (Pāli: mettā), and importantly for this essay, nonharm (Pāli: avihimsāa, or as it has entered English from Sanskrit, ahimsa). 
Nonharm includes physical nonviolence, of course, but also includes emotional or verbal nonviolence. The Pāli scriptural Dhammapāda portrays nonharm memorably: 'As a bee gathers nectar and moves on without harming the flower, its color, or its fragrance, just so should a sage walk through a village' (Fronsdal 2006, 13). Moreover, Pācitiyya rules 20 and 62 in the Pāli Vinaya rules for monks, Pācitiyya rules 116 and 143 in the Pāli Vinaya rules for nuns, and similar provisions within other Vinaya versions demand nonharm protection of the habitats in which small life forms may reside, such as bodies of water (Ṭhānissaro Bhikkhu 2007; Ṭhānissaro Bhikkhu 2013, 353, 466).

If life is found on Mars, it almost certainly will be in the form of microorganisms (Weintraub 2018, 263-269). As long as those microorganisms are treated with ethics designed for animals, given the above injunctions the planet-wide ecological manipulation of Mars appears to be morally problematic because of the possible threats it will pose to that life and its habitats. Raised temperatures, an altered atmosphere, and changed humidity on Mars could result in the destruction of indigenous life and its supportive surroundings. Although arguments exist that a manipulated Mars may allow ancient Martian life forms to exit dormancy and again flourish (McKay 2009, 258), it must be remembered that the goal of the planet-wide manipulation of Mars' ecology for proponents like Beech and Zubrin remains the comfort of Earthlings, not restoring the ecology of Mars from 4 billion years ago. Any life forms that may be dormant will be challenged, and perhaps harmed, by the unprecedented ecological conditions emerging from this strategy.

Of course, the ethical status of microorganisms remains unclear within Buddhist ethics, as it remains murky in other ethical worlds, too. For instance, in an ethnographic examination of Tibetan monastics living in India, Eisen and Konchok $(2018,38)$ found that about half of monastics who had studied microbes under a microscope decreed them as sentient and capable of suffering while the other half did not, with sentience and the ability to suffer determining one's status as a traditional Buddhist moral actor (Keown 2001, 35). Therefore, although we may surmise that the Buddha would have wanted to 
extend nonharm to Martian microbes and thus avoid large-scale ecological manipulation, other Buddhists may differ, and we may be wrong about the Buddha himself.

Buddhist scriptural responses to ecological manipulation become more opaque if no life is found on Mars. Although Buddhism maintains a substantial ethic for living entities like animals, as I have mentioned, there exists almost no environmental ethical valuation for stone or other abiotic ecologies in themselves (Capper 2015, 65-67). Buddhism treasures life that can reincarnate and therefore, as the Lankkāvatāra Sütra portrays it, is of 'the same nature' as humanity in terms of the capacity for human-like suffering (Suzuki 1973, 212); perceived lifeless things like stones, in scriptures from across Buddhist traditions, do not reincarnate or experience human-like suffering and therefore essentially exist for the service of living beings.

This situation arises in part because Buddhism posits a dimension of reality known as the sattvaloka, or realm of living beings such as humans and animals, which is synonymous with samsara, or the five- or six-tiered universe of rebirth (Harris 2007, 150). Alternatively, the bhäjanaloka, or container realm, consists of nontransmigrating entities, such as plants, minerals, and water, which provide a relatively spiritually inert backdrop for the realms of rebirth through which sentient beings transmigrate. Stone entities belong to the bhäjanaloka. Generally speaking, only sattvaloka entities enjoy moral relevance in terms of demanding moral action like that of nonharm, and bhäjanaloka entities like mineral formations and water bodies receive little ethical valuation in themselves (150). The current Dalai Lama, in fact, explicitly describes the bhäjanaloka world of stones as 'secondary' and of lesser moral value than the sattvaloka realm of beings who reincarnate (Lopez 2008, 70).

To be fair, there are special Buddhist stones, such as Japan's Fujito Stone at the Daigoji temple in Kyoto, or special collections of stones, such as China's holy Buddhist mountain Wutaishan. But beyond exceptional instances like these, for reasons that I have mentioned broad regard for stones as worthy of environmental ethical valuation remains almost entirely absent from the teachings of the Buddha as well as broader Buddhist systems. The Buddha, in fact, explicitly approved of the use of stones (Pāli: pāsāṇo) for 
constructing human buildings, walkways, footwipers, bed supports, and monastery assembly halls, among other outcomes (Ṭhānissaro Bhikkhu 2013, 346, 657, 679, 719, 736). Moreover, scriptures like the Bodhicaryāvatāra instruct that we should avoid 'breaking up clods of earth...without any purpose' (Shantideva 1995, 38), but such passages are both rare in appearance and vague in terms of what 'purpose' means.

Unfortunately, given this Buddhist worldview but also appreciating the important roles played by mineral formations in both biotic and abiotic processes, to this point Buddhist environmental ethics fail the test of robustness because they cannot adequately protect the instrumental, scientific, functional, aesthetic, and cultural value of abiotic stony places (Gray 2004, 65) like those typical of the surface of Mars. This constitutes no small problem, for only by possessing an environmental ethical relevant to the protection of abiotic geodiversity can Buddhist ethics more fully participate in activities like the praxis of climate change mitigation on Earth (Ajani et.al. 2013, 61) or protection of abiotic locales on Mars.

Therefore, especially if no life is found on Mars, Buddhist scriptures, originating in other times, supply little direction regarding both the environmental protection of abiotic locales as well as the ethics of planetary ecological manipulation. However, contemporary Buddhists, especially those from spacefaring countries like the United States, enjoy access to information that the scripture writers lacked. By consulting some of these latter-day Buddhists we find surprisingly innovative Buddhist ethical outlooks as well as some firm rejections of the proposal to make Mars more Earthlike.

\section{American Buddhists in the Ethnographic Field}

Although for this essay I collected ethnographic field data from statistically significant groups of Theravāda, Mahāyāna, and Vajrayāna Buddhists alike, here I treat American Buddhism as a nondenominational phenomenon. I do so because the qualitative scriptural injunctions that I previously mentioned appear relatively similarly in scriptures across schools. Moreover, my quantitative field data reveal no significant differences across sects as checked by pairwise two-tailed Fisher's exact statistical tests 
of independence, so that the data employed here do not incite concern with differential attitudes across sects.

Buddhism was introduced to the United States in the nineteenth century and then exploded in visibility starting in the 1950's, and since then American Buddhism has been marked by an environmentalist sensibility. The scholar of Buddhism Richard Seager $(1999,215)$ even proclaimed American Buddhism the 'eco-centric sangha' because of appearances such as strong bioregional environmentalism (Kaza 1997, 219-248), conservationist practices (Capper 2015, 59-65), and integration of environmental activism into spirituality (Koizumi 2010, 133-145). American Buddhists therefore offered two advantages for this study resulting from the ethnographic field. First, some Buddhists were eager to participate in this project since they appreciated its environmental concerns. In addition, living in the spacefaring culture of the United States, these Buddhists enjoy familiarity with the issues at hand.

Among these Buddhists I undertook survey-based field work, approved by my university's Institutional Review Board, between March and June of 2019. I chose surveys over interviews as my main ethnographic tool because I expected opinions on subjects like the planet-wide ecological manipulation of Mars to be too brief to be helpful in an interview format as well as because I wanted to touch on numerous topics as a part of a larger project. Nonetheless, copious spaces for comments on my survey as well as my physical presence in Buddhist centers amply invited additional narrative comments, some of which I share here.

In the field I obtained significant samples from all of the three Buddhist main branches of Theravāda ( $=44)$, Mahāyāna $(\mathrm{N}=40)$, and Vajrayāna $(\mathrm{N}=37)$, which, taken together, supplied 121 overall Buddhist samples. Theravāda centers studied included Center A $(\mathrm{N}=27)$, an outgrowth of the Thai Mahanikai lineage in Atlanta, Georgia, and Center B $(\mathrm{N}=17)$, which practices vipassanā meditation with eclectic Thai and Burmese roots in New Orleans, Louisiana. Center C $(\mathrm{N}=34)$ in Baton Rouge, Louisiana, supplied Vietnamese Thiền school Mahāyāna samples to supplement those derived from Center D $(\mathrm{N}=6)$, a place for the traditional practice of Sōtō Zen in New Orleans. Vajrayāna 
samples emerged from Center E (N=12), a Nyingma Buddhist community in Lafayette, Louisiana; Center F (N=10) in Covington, Louisiana, which has a hybrid Nyingma/Géluk lineage; and the Géluk-affiliated Center $\mathrm{G}(\mathrm{N}=15)$ in New Orleans.

Portraying the demographics of the centers that I studied requires a bit of theoretical discussion because of some upheaval in the study of American Buddhism. Since the 1970s the study of American Buddhism typically has followed Prebish's (1979, 171-172) 'two Buddhisms' model or Nattier's (1998, 183-195) 'three Buddhisms' model in describing American Buddhists. However, in recent years both of these models have come under attack for failing to comprehend the true nature of American Buddhist practices (Han 2017, 1-24), obscuring issues of ethnicity (Spencer 2014, 35-61), and 'unconscious white privilege' (Hickey 2010, 1-25). Respecting these critiques, in this essay I take a fresh approach.

The scholar of American Buddhism Jeff Wilson (2010, 195-208) describes how tensions at the Rochester Zen Center developed between desires to remain as faithful as possible to Asian on-the-ground models of Buddhism and goals to innovate the tradition to reflect its new American home. Such tensions remain widespread in American Buddhism beyond the Rochester Zen Center, so I utilise them to create a new understanding. Following the work of the sociologist of American religion Mark Chaves $(2017,89)$, in this essay I will define the wish to adhere as closely as possible to perceived Asian on-the-ground realities as conservative American Buddhism while I define the wish to adapt the tradition to the United States as liberal American Buddhism. With these definitions in mind, one quickly sees that there exist myriad issues on which any individual, whether an immigrant or a 'convert' (Prebish 1979, 171-172), can be conservative or liberal. In fact, it is not uncommon to find practitioners from across ethnicities who exhibit conservative-style reverence for monastics while they also follow liberal personal rules for food and drink, and there remain numerous other scenarios. The point is that here I intend a spectrum between conservative and liberal opinion positions regarding elements of Buddhist life, not conservative or liberal sociological categories for Buddhist people. 
Following this spectrum, through its membership every center will provide a home to diverse opinions of individuals on different issues. However, in order to develop stable institutional identities and follow institutional missions, centers themselves will condition their messages and practices to reflect specific orientations on the spectrum, such as a center that chooses to offer classes on meditation as self-therapy rather than to perform traditional bodhimaṇdala offering rituals for local spirits. While humans cannot be categorised by my spectrum, Buddhist centers can.

In this light, two of the seven centers that I studied should be described as mixed centers, since they intentionally purvey both conservative and liberal doctrines and practices at alternate times. The other five centers in my study were more frankly of the liberal Buddhist variety. To learn from all points of view, I reached out to a number of centers that may be considered conservative without receiving an invitation to study in those places. Perhaps my secular effort to shape Buddhist ethics to extraterrestrial realities ran against conservative points of view too much. Whatever the orientation of the centers in my study, though, my survey cohort includes practitioners with little experience with Buddhism, many long-time dedicated lay practitioners, and six monastics.

So that we may perceive American Buddhist perspectives apart from those that are more generally American, I compare Buddhist survey results with those from a control sample intended to represent the broader United States public. I created this control sample by surveying 78 random undergraduate students at a small state university in the southeastern United States, the same region as the Buddhist centers under consideration. Within this control sample self-reports of religious adherence indicated 82\% were Christian, 9\% expressed no religion, 2.6\% embraced Hinduism, and 1.3\% each reported as ecumenical, Wiccan, agnostic, Stoic, and Buddhist, with this last roughly matching the same percentage of Buddhists as that found within the general population (Mitchell 2016, 6).

Whether in the Buddhist group or in the control group, respondents took the same sixteen prompt survey that forms a part of a larger project. As a part of this process, 
participants encountered this proposal: 'We transform Mars by injecting gases into the atmosphere, thus thickening the air and warming the planet so that it is more Earthlike for future human, animal, and plant immigrants.' Then participants faced four prompts relevant to the planet-wide ecological manipulation of Mars:

1. I think that Buddhist principles should be utilised to guide our actions regarding changing Mars' ecology as proposed. (responses on a five-point scale from strongly agree to strongly disagree)

2. If we do use Buddhist principles regarding changing Mars' ecology as proposed, those principles should be? (choices offered but alternative responses welcomed)

3. Our moon and other extraterrestrial places should be valued and protected from undue harm, even if no living beings exist there. (responses on a five-point scale from strongly agree to strongly disagree)

4. Human beings have the right to change the ecologies of other planets, as long as no living beings are present. (responses on a five-point scale from strongly agree to strongly disagree)

American Buddhists in this study responded to these prompts in some astonishing ways because they offer brilliant examples of folk Buddhist respect for rocks and abiotic places while they also significantly reject Beech's and Zubrin's pleas to manipulate the ecology of Mars. Now I turn to these results.

\section{Ethnographic results}

Room for environmental ethics innovation emerges first in Buddhist responses to the prompt, 'I think that Buddhist principles should be utilised to guide our actions regarding changing Mars' ecology as proposed.' Among Buddhists 81.8\% (99/121) agreed or strongly agreed with applying Buddhist principles to this proposed planet-wide ecological manipulation, despite the awareness among many field subjects that Mars may be lifeless. Only 5.8\% (7/121) of Buddhists felt that Buddhist ethics were not relevant to manipulating planetary ecologies, with $12.4 \%$ (15/121) remaining neutral. Conversely, 
and unsurprisingly, members of the primarily Christian (82\%) control group were much less sanguine about applying Buddhist ethics (fewer than $10 \%$ strongly agreed that Buddhism should be in the conversation), with the independence between Buddhist and control samples demonstrated with a Fisher's exact statistical test of independence $\mathrm{p}<0.0001$.

With these Buddhists' distinctively asserting the appropriateness of utilising Buddhist principles on Mars, the next prompt encouraged Buddhists to choose which principles to apply to planet-wide ecological manipulation scenarios. Recognising that Buddhists ethics are not a zero-sum game and multiple principles can apply simultaneously, respondents were allowed to choose or provide principles as they wished. As Table 1 indicates, a massive $87.6 \%$ of Buddhists (106/121) chose the fundamental Buddhist philosophical principle of dependent arising, or pațiccasamuppāda in the Pāli language, as an operational ethical platform on Mars. This key Buddhist principle asserts that since all existents arise from one or more causes, no existents manifest independently in time or space, so that all of physical reality emerges interdependently. Thus, against the dualistic notions of Beech, Zubrin, and Stoner that presume a separation between humans and the rest of the natural world, these Buddhists more ecocentrically chose to spotlight their interrelatedness with Mars and its features. Perhaps this outcome is not unexpected, given that pațiccasamuppāda dependent arising remains a well-used tool in the Buddhist environmental ethics toolbox. Nonetheless, the implicit folk ethical model that is collectively employed by these Buddhists arises as one of inclusiveness among humans and nonhumans rather than that of the superior human conquest of inferior nature that Beech and Zubrin openly encourage.

Table 1 here

Although the Buddhist concept of dependent arising is in itself ethically neutral (Goleman 2018,10), these Buddhists charge it morally by combining it with ethical injunctions, most especially that of ahimsa nonharm. After dependent arising, at $81.8 \%$ $(99 / 121)$ the second most common choice among Buddhists in terms of principles to apply to planetary ecological manipulation emerged from the survey choice of 'the First 
Precept, on not harming others.' In combining dependent arising with nonharm in this way, the implicit folk ethical reasoning here creatively facilitates innovative Buddhist relationships with abiotic stones. As described above, in the scriptures nonharm generally should be directed only to living beings. Yet in substantial numbers these American Buddhists inventively extend nonharm to planetary features that are presumed to be abiotic. Uniquely these Buddhists add an abiotic dimension to the combination of dependent arising and nonharm contained within Traphagan and Traphagan's (2015, 303304) description of Buddhism that 'all things in the world are interrelated and interdependent. As a result, to cause harm to one point in the network implies the causing of harm to all other nodes.'

Following this original extension of a combination of dependent arising and nonharm, the Buddhist response to the third survey prompt has the opportunity beneficially to revolutionise Buddhist environmental ethics in addition to maintaining relevance to Mars itself. With the prompt, 'Our moon and other extraterrestrial places should be valued and protected from undue harm, even if no living beings exist there,' $66.9 \%$ of Buddhists strongly agreed while another $21.5 \%$ agreed, leaving a unexpectedly remarkable $88.4 \%(107 / 121)$ of Buddhists in favor of extending ahimsa respect and protection to abiotic places like may be typical of Mars. Although, as I have described, there exists little scriptural basis for this type of nonharm protection of abiotic stony spots, in the folk environmental ethics of these Buddhists one finds clear respect for abiotic ecologies. With a Fisher's exact test $\mathrm{p}<0.001$, these Buddhists also stood out from members of the control sample, only $26.9 \%$ of whom strongly agreed with the prompt, as Table 2 shows. It takes more than one cohort of Buddhists to change the course of Buddhist environmental ethics, but these Buddhists, besides being divergent in their outlooks from the general population, vibrantly accentuate the reality that the Buddhist tradition should renovate itself in terms of its abiotic environmental ethics.

Table 2 here

Most fascinatingly, as an outgrowth of their extension of interrelatedness and nonharm into abiotic realms, these Buddhists on the whole oppose turning Mars into 
something like Earth's twin. As one can see in Table 3, of American Buddhists in this study $52 \%(63 / 121)$ either disagreed (26.4\%) or strongly disagreed (25.6\%) with the prompt, 'Human beings have the right to change the ecologies of other planets, as long as no living beings are present.' Outnumbered roughly two-to-one, only 26\% (31/121) of Buddhists either agreed (14.9\%) or strongly agreed (10.7\%). Comments from Buddhists included, 'I'm really opposed to changing Mars' climate,' 'Not sure we should change Mars,' as well as, 'Mars' nature is perfect now.' Representing the minority, one Buddhist said, 'Consider compassion for future inhabitants of Mars, even if no resident life is found,' while another asserted, 'Terraforming is cool.' Thus, while not complete, general Buddhist rejection of the right of humans to change large-scale the ecologies of other planets remains potent, with twice as many Buddhists disapproving rather than approving.

Table 3 here

Interestingly, as with Buddhists about 52\% (40/78) of the control sample also either disagreed or strongly disagreed that humans have the right to manipulate other planets in the large-scale. However, 37.2\% (29/78) of members of the control sample expressed agreement or strong agreement with the prompt, indicating a greater sense of right to manipulate Mars than Buddhists appear to possess. A Fisher's exact test returned an ambiguous result of $\mathrm{p}=0.0798$ on this count, meaning that at a $10 \%$ level of significance the Buddhists arise as numerically distinct from the control sample but not so at a $5 \%$ level of significance. Nevertheless, contrary to the wishes of Beech and Zubrin even members of the control group mostly agree with Buddhists in expressing that humans lack the ethical right to engage in the planet-wide ecological manipulation of Mars.

While this cohort of Buddhists by itself does not provide a definitive, once-andfor-all change in Buddhist ethics with its expansion of the reach of nonharm, the Buddhists in this group still supply a useful new voice which helpfully responds to a great weakness of Buddhist environmental ethics, the protection of abiotic entities. Now it is time to explore what results like these mean. 


\section{Discussion}

Although just one grouping of individuals from only one religion, these American Buddhists make contributions both to space studies as well as to the positive development of Buddhist environmental ethics. For instance, twice as many of these Buddhists deny human beings the right to engage in the planet-wide ecological manipulation of Mars as approve of the practice. From this point of view, Beech's enthusiastic favoritism toward humans as a motive for ecological manipulation fails in terms of providing proper ethical justification. Likewise, Zubrin's exclusive valuing of life falls before American Buddhist calls for humans to protect both living and nonliving entities, given that, apparently to these Buddhists, humans have duties to more than just life. This shift reflects the words of the ethicist James S. J. Schwartz, 'If too much emphasis is placed on life, we may blind ourselves to reasons for preserving other kinds of environments' (Schwartz 2016a, 102). In the end, these Buddhists provide space studies with an ethical rebuke of the proposal to make Mars dramatically more Earthlike.

More foundationally, Buddhists offer this perspective by implicitly relying on a different model for understanding humanity's place in the universe. Beech's human favoritism, Zubrin's sense of conquering Mars in the name of life, and Stoner's concept of 'wilderness' all betray dualistic understandings of human separation from nature. Conversely, these Buddhists spotlight a new, nondualist understanding of humanity's place in the universe, in which human beings, interconnected with the rest of physical reality, exist as counterparts of, rather than overlords of, the rest of the larger natural world. From this, Buddhists express a need to take responsibility not just for human welfare as an aspect of existence but also for human interactions with the larger nonhuman world, including taking responsibility for interactions with stones.

The environmental model employed by these Buddhists, being relational in character, can provide ethical and scientific benefits to space studies, as Mark Lupisella (2016, 81-82) indicates, while the Buddhist extension of the moral community beyond simply humans moves us toward the 'cosmic ethic of environmental protection' 
requested by the astrobiologist Charles $\mathrm{S}$. Cockell (2007, 31). In addition, with the expansion of the limits of nonharm based upon notions of interconnectedness, the Buddhist notion of dependent arising operationally 'offers a philosophical basis for a meaningful astroethical paradigm' by providing a 'unique possibility of embracing the totally other in a far more liberated way' (Irudayadason 2013, 101, 108). Finally, by responding to the lament of the physicist Victor Mansfield that 'it is more urgent than ever that we find a coherent worldview that can guide our science and our moral actions,' (Mansfield 2003, 319), these Buddhists provide space sciences with such direction in their yoking of folk ethical notions of interconnectedness and nonharm toward Mars.

Moreover, and importantly for Buddhist environmental ethics, this interactive model of connectedness, for these Buddhists anyway, provokes the extension of the traditional Buddhist value of nonharm beyond traditional boundaries, so that abiotic ecologies become protected by the umbrella of ahimsa. In this study this folk Buddhist ethical sensibility distinguishes itself not only categorically from the American mainstream culture but also from many traditional Buddhist teachings that overlook the instrumental, functional, educational, and cultural value of abiotic locales like mineral formations (Gray 2004, 65) that presumably appear on the surface of Mars. The space ethicist William R. Kramer $(2011,257)$ writes, 'In the context of space exploration we are provided a rare moment to craft policies that reconsider what is ethical and what is not,' and these American Buddhists react positively and constructively to this opportunity.

This innovation regarding Buddhist regard for abiotic locales remains significant. As I have argued, an inability to protect the nonliving, such as stones, exists as a great weakness within traditional Buddhist environmental ethics, preventing the useful application of Buddhist ethics to a variety of situations. Take, for example, Earth's climate crisis. While obviously an atmospheric problem, climate change also is a mineral problem, since the carbon cycle has been disrupted and carbon that following natural processes should be in the ground has been released into the atmosphere instead (Rigopoulos et al. 2018, 197). Hence, one set of strategies for mitigating climate change 
involves lithospheric carbon sequestration, which absorbs carbon dioxide from the air into minerals, typically via chemical reactions in seawater, through the management of stone ecologies (Morton 2015, 249-259). Rigopoulos et al. (2018, 199-205), for instance, demonstrate the effectiveness of using submerged dunite to transform atmospheric $\mathrm{CO}_{2}$ into aragonite mineral precipitates. A Buddhism that extends a measure of nonharm to mineral formations can provide moral direction to ensure environmental responsibility within carbon sequestration strategies like these, in this way becoming ethically more capable in the struggle with Earth's climate change. The folk Buddhist ethical innovations found in this article regarding the valuation of lifeless entities thereby bear serious positive ramifications for Buddhist environmental ethics on Earth despite their development in the context of protecting the environment of Mars.

\section{Conclusion}

In Brian W. Aldiss's futuristic novel White Mars, Martian colonists insist that to be on Mars is to experience the planet's ethereal beauty and therefore to realise the grave mistake that planet-wide ecological manipulation represents (Aldiss 1999, 16). As a result, colonists pursue a non-manipulated Mars as a place of 'wonder and meditation' (9), and perhaps the American Buddhists in this study seek a similar vision. Collectively they reject the large-scale ecological manipulation of Mars, stressing instead their connectedness with the planet and its environs. Expanding the reach of the traditional value of nonharm through a folk Buddhist environmental ethic, they provide a powerful new direction for Buddhist moral sensibilities by ameliorating a troublesome weakness, the inability to protect stones and other abiotic phenomena. Although just one grouping of Buddhists, these Americans help to improve scholarship by providing useful moral insights to space studies while simultaneously delineating positive directions for growth for Buddhist environmental ethics on Earth. 


\section{References}

Ajani, Judith I., Heather Keith, Margaret Blakers, Brendan G. Mackey, and Helen P. King. 2013. 'Comprehensive carbon stock and flow accounting: A national framework to support climate change mitigation policy.' Ecological Economics 89: 61-72. https://doi.org/10.1016/j.ecolecon.2013.01.010.

Aldiss, Brian W. 1999. White Mars. New York: St. Martin's Press.

Beech, Martin. 2009. Terraforming: The Creating of Habitable Worlds. New York: Springer.

Capper, Daniel. 2015. 'Learning Love from a Tiger: Approaches to Nature in an American Buddhist Monastery.' Journal of Contemporary Religion 30 (1): 53-69. https://doi.org/10.1080/13537903.2015.986976.

. 2016a. Learning Love from a Tiger: Religious Experiences with Nature. Oakland: University of California Press.

_. 2016b. 'Animism among Western Buddhists.' Contemporary Buddhism 17 (1): 30-48. https://doi.org/10.1080/14639947.2016.1189130.

Chaves, Mark. 2017. American Religion: Contemporary Trends. Princeton: Princeton University Press.

Cockell, Charles S. 2007. Space on Earth: Saving Our World by Seeking Others. London: Macmillan.

Cronon, William. 1995. 'The Trouble with Wilderness; Or, Getting Back to the Wrong Nature.' In Uncommon Ground: Toward Reinventing Nature, edited by W. Cronon, 69-90. New York: Norton.

Eisen, Arri, and Yungdrung Konchok. 2018. The Enlightened Gene: Biology, Buddhism, and the Convergence that Explains the World. Lebanon: ForeEdge.

Fogg, Martyn J. 1995. Terraforming: Engineering Planetary Environments. Warrendale: Society of Automotive Engineers.

Fronsdal, Gil. 2006. The Dhammapada. Boston: Shambhala.

Genta, Giancarlo. 2017. Next Stop Mars: The Why, How, and When of Human Missions. Cham: Springer. 
Goleman, Daniel. 2018. 'Ecology, Ethics, and Interdependence.' In Ecology, Ethics, and Interdependence: The Dalai Lama in Conversation with Leading Thinkers on Climate Change, edited by John Dunne and Daniel Goleman, 9-12. Somerville: Wisdom Publications.

Graham, James M. 2004. 'The Biological Terraforming of Mars: Planetary Ecosynthesis as Ecological Succession on a Global Scale.' Astrobiology 4 (2): 168-195. https://doi.org/10.1089/153110704323175133.

Gray, Murray. 2004. Geodiversity: Valuing and Conserving Abiotic Nature. West Sussex: John Wiley and Sons.

Han, Chenxing. 2017. 'Diverse Practices and Flexible Beliefs among Young Adult Asian American Buddhists.' Journal of Global Buddhism 18: 1-24. http://dx.doi.org/10.5281/zenodo.1247854.

Harris, Ian. 2007. 'Landscape Aesthetics and Environmentalism: Some Observations on the Representations of Nature in Buddhist and Western Art.' Contemporary Buddhism 8 (2): 149-168. https://doi.org/10.1080/14639940701636125.

Haynes, Robert. 1990. 'Ecce Ecopoiesis: Playing God on Mars.' In Moral Expertise: Studies in Practical and Professional Ethics, edited by Don MacNiven, 161-83. London, UK: Routledge.

Hickey, Wakoh Shannon. 2010. 'Two Buddhisms, Three Buddhisms, and Racism.' Journal of Global Buddhism 11: 1-25. http://www.globalbuddhism.org/jgb/index.php/jgb/article/view/112.

Irudayadason, Nishant Alphonse. 2013. 'The Wonder Called Cosmic Oneness: Toward Astroethics from Hindu and Buddhist Wisdom and Worldviews.' In Encountering Life in the Universe, edited by Chris Impey, Anna H. Spitz, and William Stoeger, 94-119. Tucson: University of Arizona Press.

Jakosky, Bruce M., and Christopher S. Edwards. 2018. 'Inventory of $\mathrm{CO}_{2}$ Available for Terraforming Mars.' Nature Astronomy 2: 634-639. https://doi.org/10.1038/s41550-018-0529-6. 
Kaza, Stephanie. 1997. 'American Buddhist Response to the Land: Ecological Practice at Two West Coast Retreat Centers.' In Buddhism and Ecology, edited by Mary Evelyn Tucker and Duncan Ryūken Williams, 219-248. Cambridge: Harvard University Press.

Keown, Damien. 2001. Buddhism and Bioethics. New York: Palgrave.

Koizumi, Tetsunori. 2010. 'The Noble Eightfold Path as a Prescription for Sustainable Living.' In How Much is Enough? Buddhism, Consumerism, and the Human Environment, edited by Richard K. Payne, 133-145. Somerville: Wisdom Publications.

Kramer, William R. 2011. 'Colonizing Mars-An Opportunity for Reconsidering Bioethical Standards and Obligations to Future Generations.' Futures 43: 545551. https://doi.org/10.1016/j.futures.2011.02.006.

Lopez, Donald S. Jr. 2008. Buddhism and Science: A Guide for the Perplexed. Chicago: University of Chicago Press.

Loy, David R. 2018. Ecodharma: Buddhist Teachings for the Ecological Crisis. Somerville: Wisdom Publications.

Lupisella, Mark. 2016. 'Cosmological Theories of Value: Relationalism and Connectedness as Foundations for Cosmic Creativity.' In The Ethics of Space Exploration, edited by James S. J. Schwartz and Tony Milligan, 75-91. Cham: Springer.

Mansfield, Victor. 2003. 'Time and Impermanence in Middle Way Buddhism and Modern Physics.' In Buddhism and Science: Breaking New Ground, edited by B Alan Wallace, 305-321. New York: Columbia University Press.

McKay, Christopher P. 2009. 'Planetary Ecosynthesis on Mars: Restoration Ecology and Environmental Ethics.' In Exploring the Origin, Extent, and Future of Life: Philosophical, Ethical, and Theological Perspectives, edited by Constance M. Bertka, 245-260. Cambridge: Cambridge University Press. Milligan, Tony. 2015. Nobody Owns the Moon: The Ethics of Space Exploitation. Jefferson: McFarland and Company. 
Mitchell, Scott A. 2016. Buddhism in America: Global Religion, Local Contexts. London: Bloomsbury.

Morton, Oliver. 2015. The Planet Remade: How Geoengineering Could Change the World. Princeton: Princeton University Press.

Nattier, Jan. 1998. 'Who is a Buddhist? Charting the Landscape of Buddhist America.'

In The Faces of Buddhism in America, edited by Charles S. Prebish and Kenneth K. Tanaka, 183-195. Berkeley: University of California Press.

Prebish, Charles S. 1979. American Buddhism. North Scituate: Duxbury Press.

Rigopoulos, Ioannis, Anna L. Harrison, Andreas Delimitis, Ioannis Ioannou, Angelos M. Efstathiou, Theodora Kyratsi, and Eric H. Oelkers. 2018. 'Carbon sequestration via enhanced weathering of peridotites and basalts in seawater.' Applied Geochemistry 91: 197-207. https://doi.org/10.1016/j.apgeochem.2017.11.001.

Robinson, Kim Stanley. 1993. Red Mars. New York: Del Rey. . 1994. Green Mars. New York: Del Rey. . 1996. Blue Mars. New York: Del Rey.

Schwartz, James S. J. 2013. 'On the Moral Permissibility of Terraforming.' Ethics and the Environment 18 (2): 1-31. https://www.jstor.org/stable/10.2979/ethicsenviro.18.2.1. . 2016a. 'On the Methodology of Space Ethics.' In The Ethics of Space Exploration, edited by James S. J. Schwartz and Tony Milligan, 93-107. Cham: Springer.

. 2016b. 'Where No Planetary Protection Policy Has Gone Before.' Proceedings of Tennessee Valley Interstellar Workshop 2016, Chattanooga, Tennessee, 30-36.

Seager, Richard H. 1999. Buddhism in America. New York: Columbia University Press. Shantideva. 1995. The Bodhicaryāvatāra. Translated by Andrew Skilton and Kate Crosby. Oxford: Oxford University Press.

Sparrow, Robert. 1999. 'The Ethics of Terraforming.' Environmental Ethics 21: 227-45. https://doi.org/10.5840/enviroethics199921315. 
Spencer, Anne C. 2014. 'Diversification in the Buddhist Churches of America:

Demographic Trends and Their Implications for the Future Study of U.S.

Buddhist Groups.' Journal of Global Buddhism 15: 35-61.

http://dx.doi.org/10.1.1.670.7912-1.

Stoner, Ian. 2017. 'Humans Should Not Colonize Mars.' Journal of the American

Philosophical Association 3 (3): 334-353. https://doi.org/10.1017/apa.2017.26.

Suzuki, Daisetz Teitaro. 1973. The Lankavatara Sutra: A Mahayana Text. London:

Routledge and Kegan Paul.

Ṭhānissaro Bhikkhu. 2007. 'Bhikkhunī Pāṭimokkha.'

https://www.accesstoinsight.org/tipitaka/vin/sv/bhikkhuni-pati.html.

Țhānissaro Bhikkhu. 2013. The Buddhist Monastic Code I and II. Valley Center: Metta Forest Monastery.

Traphagan, John W., and Julian W. Traphagan. 2015. 'SETI in Non-Western

Perspective.' In The Impact of Discovering Life beyond Earth, edited by Steven J.

Dick, 299-307. Cambridge: Cambridge University Press.

Turner, Frederick. 2011. Genesis: An Epic Poem of the Terraforming of Mars. Spokane Valley: Ilium Press.

Weintraub, David A. 2018. Life on Mars: What to Know before We Go. Princeton: Princeton University Press.

Wilson, Jeff. 2010. "AA Dharma of Place”: Evolving Aesthetics and Cultivating Community in an American Zen Garden.' In American Buddhism as a Way of Life, edited by Gary Storhoff and John Whalen-Bridge, 195-208. Albany: State University of New York Press.

Zubrin, Robert. 1996. The Case for Mars: The Plan to Settle the Red Planet and Why We Must. London: Simon and Schuster.

Tables 
Table 1. If we do use Buddhist principles regarding changing Mars' ecology as proposed, those principles should be:

\begin{tabular}{lcc}
\hline N=121 & Frequency & Percent \\
\hline Interconnected universe & 106 & 87.6 \\
Nonharm & 99 & 81.8 \\
Compassion & 78 & 64.5 \\
Lovingkindness & 68 & 56.2 \\
Not sure & 6 & 5.0 \\
Conscientiousness & 1 & 0.8 \\
Mars' nature perfect now & 1 & 0.8 \\
Meditation & 1 & 0.8 \\
Personhood & 1 & 0.8 \\
\hline
\end{tabular}


Table 2. Our moon and other extraterrestrial places should be valued and protected from undue harm, even if no living beings exist there.

\begin{tabular}{llccc}
\hline Fisher's exact $\mathrm{p}<0.0001$ & Frequency & Percent & $\begin{array}{c}\text { Cumulative } \\
\text { Percent }\end{array}$ \\
\hline Buddhist & Strongly agree & 81 & 66.9 & 66.9 \\
& Agree & 26 & 21.5 & 88.4 \\
& Neutral & 10 & 8.3 & 96.7 \\
& Disagree & 1 & 0.8 & 97.5 \\
& Strongly disagree & 3 & 2.5 & 100.0 \\
& Total & 121 & 100.0 & \\
\hline Control & Strongly agree & 21 & 26.9 & 26.9 \\
& Agree & 35 & 44.9 & 71.8 \\
& Neutral & 10 & 12.8 & 84.6 \\
& Disagree & 10 & 12.8 & 97.4 \\
& Strongly disagree & 2 & 2.6 & 100.0 \\
& Total & 78 & 100.0 & \\
\hline
\end{tabular}


Table 3. Human beings have the right to change the ecologies of other planets, as long as no living beings are present.

\begin{tabular}{llccc}
\hline Fisher's exact $\mathrm{p}=0.0798$ & Frequency & Percent & $\begin{array}{c}\text { Cumulative } \\
\text { Percent }\end{array}$ \\
\hline Buddhist & Strongly agree & 13 & 10.7 & 10.7 \\
& Agree & 18 & 14.9 & 25.6 \\
& Neutral & 27 & 22.3 & 47.9 \\
& Disagree & 32 & 26.4 & 74.4 \\
& Strongly disagree & 31 & 25.6 & 100.0 \\
& Total & 121 & 100.0 & \\
\hline Control & Strongly agree & 10 & 12.8 & 12.8 \\
& Agree & 19 & 24.4 & 37.2 \\
& Neutral & 9 & 11.5 & 48.7 \\
& Disagree & 27 & 34.6 & 83.3 \\
& Strongly disagree & 13 & 16.7 & 100.0 \\
& Total & 78 & 100.0 & \\
\hline
\end{tabular}

